International Research Journal of Management, IT \& Social Sciences
Available online at https://sloap.org/journals/index.php/irjmis/
Vol. 6 No. 6, November 2019, pages: 58 67
ISSN: 2395-7492
https://doi.org/10.21744/irjmis.v6n6.762

\title{
Effect of Task Complexity and Time Pressure on Auditor Performance with Compensation and Organizational Citizenship Behavior (OCB) as Moderation
}

\begin{abstract}
I Wayan Adnyana ${ }^{a}$ Ni Putu Sri Harta Mimba ${ }^{\text {b }}$

Article history:

Received: 09 June 2019

Accepted: 30 September 2019

Published: 14 October 2019

\section{Keywords:}

auditor performance; compensation; organizational citizenship behavior; task complexity; time pressure;

Abstract

This study aims to examine the effect of task complexity and time pressure on auditor performance at the Public Accounting Firm (KAP) in Bali Province with compensation and organizational citizenship behavior (OCB) as moderating. The population in this study were all KAP auditors in Bali Province registered in the Directory published by the Indonesian Institute of Certified Public Accountants (IAPI) in 2017. The sampling technique used was purposive sampling. The criteria are: the auditor works in a KAP throughout the Province of Bali who is still actively operating and has a minimum work period or audit experience of 1 year. 61 questionnaire data were processed. The results of this study found that: task complexity has a negative effect on auditor performance, time pressure has a negative effect on auditor performance. The results also show that compensation is not able to moderate the influence of task complexity and time pressure on auditor performance. Organizational citizenship behavior (OCB) is not able to moderate the influence of task complexity on auditor performance but is able to moderate the influence of time pressure on auditor performance.
\end{abstract}

2395-7492@ Copyright 2019. The Author. This is an open-access article under the CC BY-SA license (https://creativecommons.org/licenses/by-sa/4.0/) All rights reserved.

\section{Author correspondence:}

I Wayan Adnyana,

Faculty of Economics and Business Udayana University, Denpasar, Indonesia.

Email address: iwayanadnyana492@gmail.com

\section{Introduction}

Auditors will continue to be faced with things that can potentially lead to performance degradation such as the complexity of the task. Tasks are often the main consideration in accounting decision making compared to individual factors. This is because assignments in accounting are more varied and have a higher level of difficulty. Auditors are usually faced with tasks that are many, varied, and interrelated between tasks with one another. A large number of

\footnotetext{
${ }^{a}$ Udayana University, Denpasar, Indonesia

${ }^{\mathrm{b}}$ Udayana University, Denpasar, Indonesia
} 
financial reports and information from management that must be examined causes the ability to resolve and memory that is not undeniably limited can affect the performance produced by an auditor.

The task complexity in this study is interpreted as the individual's perception of a task due to the limited capabilities and memory, and the ability to integrate the problems that decision-makers have (Jamilah et al., 2007). An assignment can be felt difficult for an auditor, but not so for other auditors (Restuningdiah \& Indriantoro, 2000).

The researchers found that there were some inconsistent research results regarding task complexity variables. The results of research conducted by Libby \& Lipe (1992), show that task complexity is used as a motivational tool to improve the quality of work of an auditor because auditors will try to find more knowledge which will later be useful in helping solve the problem. So the complexity of the task will make the auditor improve the quality of his work. The opposite results were obtained from the research conducted by Sanusi et al., (2007), who show that when auditors have complex or not well-structured tasks, as high as any auditor's efforts it will be difficult to complete the work properly so that it decreases the auditor's performance. Restuningdiah \& Indriantoro (2000), state that increasing the complexity of tasks or systems will reduce the success of the task. Because the increasing complexity of the task will lead to an increase in the number of jobs that must be handled by the auditor, where the auditor itself has a certain time limit in completing the task.

Auditors also often face conditions related to time constraints in completing tasks and various complex problems that are usually given by clients. So in addition to the complexity of the task, the auditor's time pressure is an unavoidable situation when facing a competitive climate. Time pressure is an obstacle that arises due to limited time to the auditor in carrying out audit assignments (Liyanarachchi \& McNamara, 2007). Time pressures can occur due to sudden assignments, relatively large assignments with fewer fees, competitive climate accounting firms, company profitability, and limited personnel (Gayatri \& Suputra, 2016; Aditya \& Kusuma, 2019). Auditors are required to be able to allocate time appropriately in determining the number of audit fees. Allocation of time in conducting audits is very influential on audit costs because too long allocation of time will increase audit costs. The audit should be completed on time or faster than the specified time in order to have a good impact on the auditor in receiving audit fees (Jemada \& Yaniartha, 2013; Juliantini et al., 2019). This affected the opinion of Ahituv et al., (1998), which states that time budget pressure is a factor that influences a person's performance.

Lautania (2011), found that time pressure negatively affected auditor performance. This indicates that the auditor feels pressured by the time pressure. Time pressure can lead to stress on the auditor and will encourage the auditor to violate audit standards or dysfunctional audits that will result in poor auditor performance. On the results of the study Basuki \& Mahardani (2006), showed that time budget pressure has a positive and significant influence directly on audit performance. The existence of a tight time budget has been considered a common thing and is a way to encourage auditors to work harder and more efficiently. Whereas, the research of Gayatri \& Suputra (2016), states that time pressure has no effect on auditor performance. This is because the auditor has had an appropriate time allocation in accordance with the complexity of the audit assignment so that the audit work can be completed efficiently and on time.

Based on the research exposure, the effect of task complexity and time pressure on auditor performance was found to be varied/inconsistent or controversial which was allegedly due to other factors that influenced the relationship between independent variables and dependent variables. Govindarajan (1986), states that the possibility of the absence of unity of research results depends on certain factors or better known as contingency factors. Murray (1990), explains that in order to reconcile conflicting results a contingency approach is needed to identify other variables that act as moderators or mediators in the research model. Conceptually and the results of empirical research, there are several variables that are thought to play a role in moderating the influence of task complexity and time pressure on auditor performance, one of which should be considered, namely compensation. It is expected that with the compensation variable as a motivation that supports auditor performance, the auditor is expected to be better able to carry out his work.

In addition to compensation variables, the variable organizational citizenship behavior (OCB) also plays an important role in auditor performance. Organizational Citizenship Behavior (OCB) is an individual behavior that is free, not directly or explicitly recognized in the reward system and in promoting effective functioning of the organization or in other words OCB is the behavior of employees that exceeds the required role, which is not directly or explicitly recognized by formal reward system (Podsakoff et al., 2000). Free in the sense that the behavior is not a requirement that must be carried out in a particular role or job description or behavior that is a personal choice (Podsakoff et al., 2000). By having this OCB behavior, the auditor can play an extra role beyond the demands of formal work, and not be egocentric. All organizations need potential and productive employees to function (Cascio in Teresia and Suyasa, 2008). Companies need workers who not only work in accordance with their main tasks to complete their

Adnyana, I. W., \& Mimba, N. P. S. H. (2019). Effect of task complexity and time pressure on auditor performance with compensation and organizational citizenship behavior (OCB) as moderation. International Research Journal of Management, IT and Social Sciences, 6(6), 58-67. https://doi.org/10.21744/irjmis.v6n6.762 
tasks if they want to function effectively, but also do things outside the job description for example by helping coworkers to complete tasks when work colleagues face many tasks, even though it is not their duties and responsibilities. This organizational citizenship behavior (OCB) in attribution theory is internal forces.

\section{Literature Review and Hypothesis Development}

\section{The Effect of Task Complexity on Auditor Performance}

Research conducted by (Sanusi et al., 2007; Septian \& Astika, 2019), shows that high task complexity has a negative effect and can reduce auditor performance. These results indicate that when the auditor has a complex or not wellstructured assignment, no matter how high the auditor's efforts will be difficult to complete the work properly so that it decreases the auditor's performance. Restuningdiah \& Indriantoro (2000), states that the existence of a high level of difficulty and variability in audit assignments can reduce auditor performance in carrying out tasks assigned to reduce auditor performance. So with the existence of high task complexity will cause the performance of an auditor will decrease due to his inability to complete the task so that it can have an impact on poor audit quality. Task complexity arises due to the lack of ability to handle a job well. The number of tasks and the level of difficulty of the task that is getting higher causes stress levels to increase. Because stress levels increase, performance will decrease. Performance decreases due to the auditor's inability to complete his task. So based on the theory and empirical data obtained from previous research, the researcher concludes that the more or more complex tasks performed by the auditor cause the auditor's performance to decline, and this will cause the auditor more difficult to think in making decisions. Based on the theoretical description, logical thinking framework, results of empirical research described above, the following hypotheses can be developed:

H1: Task complexity has a negative effect on the performance of auditor KAP in Bali Province.

\section{The Effect of Time Pressure on Auditor Performance}

Lautania (2011), and stated that time pressure has a negative effect on auditor performance. This indicates that the auditor feels pressured by the time pressure, which can lead to stress on the auditor and will eventually encourage the auditor to violate audit standards or dysfunctional audits that will result in poor auditor performance. Basuki \& Mahardani (2006) concluded that the existence of a strict time budget was considered a common thing and was a way to encourage auditors to work harder and more efficiently. These results indicate the importance of placing appropriate values on the audit function to ensure adequate time budgets. So based on the theory and empirical data obtained from previous research, the researcher concludes that the more auditors are limited or experiencing pressure in finding audit findings, it affects auditor's performance, which tends to be lower. Based on the theoretical description, logical thinking framework, results of empirical research described above, the following hypotheses can be developed:

H2: Time pressure has a negative effect on the performance of auditor KAP in Bali Province.

\section{Compensation Moderating Task Complexity on Auditor Performance}

Research conducted by Dhermawan et al., (2012), states that compensation for performance shows a positive and significant influence on the environment of the Bali provincial public works office. This means that the increase in compensation will have an impact on improving the performance of employees and vice versa if the compensation given by the company to employees is less or not good, then the impact that occurs in the company is that employee performance will be low. Fitrianasari et al., (2013), found that financial and non-financial compensation felt in accordance with the expectations of nurses would be able to improve nurse performance. This means that compensation has a significant effect on nurse performance. Compensation and nurse performance are positively related, which means that the higher the compensation felt by nurses, the higher the nurse's performance. Supatmi et al., (2013), found that compensation has a significant effect on employee performance. Compensation and employee performance are positively related, which means that the higher the compensation felt by employees, the higher the employee's performance. Compensation can increase or decrease employee performance. Appropriate compensation is able to provide encouragement to increase one's morale. The right compensation means that compensation is in accordance with the needs and in accordance with the work done. So based on the theory and empirical data obtained from previous research, the researcher concludes that by giving the right compensation to the auditor, as complex as the duties that the auditor has, the auditor will try more in carrying out or completing tasks and this will improve his performance. 
Based on the theoretical description, logical thinking framework, results of empirical research described above, the following hypotheses can be developed:

H3: Compensation weakens the negative effect of task complexity on the performance of auditor KAP in Bali Province.

Compensation Moderating Time Pressure on Auditor Performance

Sososutikno (2003), states that time pressure is a condition that shows that the auditor is required to make efficiency on the time budget that has been prepared or there are a very tight and rigid time and budget restrictions. In this case the auditor will feel pressured by the demands experienced. From these problems, it is necessary to have motivation to support the auditor's performance to remain stable. In this study researchers used compensation to motivate auditor performance compensation is one of the goals of a job. A person will feel calm when the reciprocity that will be given is in accordance with what he has done. For most people compensation is important because it concerns the needs of each individual. So based on the theory and empirical data obtained from previous research, the researcher concludes that with the right compensation, the auditor can overcome the time pressure he is experiencing such as giving up his time to do overtime and of course this will improve his performance. Based on the theoretical description, logical thinking framework, results of empirical research described above, the following hypotheses can be developed:

H4: Compensation weakens the negative effect of time pressure on the performance of auditor KAP in Bali Province.

\section{Organizational Citizenship Behavior (OCB) Moderating Task Complexity on Auditor Performance}

Robbins \& Judge (2008), put forward facts that show that organizations that have employees who have OCB (Organizational Citizenship Behavior) are good, will have better performance than other organizations. Positive employee behavior will be able to support individual performance and organizational performance for better organizational development (Winardi \& Musnadi, 2012; Putra \& Sudana, 2019). OCB provides benefits so that someone is able to carry out work without prioritizing rewards. So based on the theory and empirical data obtained from previous research, the researcher concludes that by having this behavior, an auditor will always look for additional information or knowledge related to his work and try to complete any complex task that exists so as to improve its performance. Based on the theoretical description, logical thinking framework, results of empirical research described above, the following hypotheses can be developed:

H5: Organizational Citizenship Behavior (OCB) weakens the negative effect of task complexity on the performance of auditor KAP in Bali Province.

\section{Organizational Citizenship Behavior (OCB) Moderates Time Pressure on Auditor Performance}

The results of Fitriastuti (2013), Organizational Citizenship Behavior (OCB) have a significant positive effect on employee performance. By having this OCB behavior, the employee will not question the time pressure given by the company or the client. So based on the theory and empirical data obtained from previous research, the researchers concluded that by having Organizational Citizenship Behavior (OCB), the auditor will carry out all his work happily, which later will not question the time that will be used by the auditor in completing the task - his duty. Auditors will also always do overtime or use holidays to complete their work. In addition to improving the performance of the auditor itself, this will also improve the performance of his teammates or office colleagues, because someone who has OCB will always help the work of his colleague, where beforehand he will be able to handle his work to the fullest. Based on the theoretical description, logical thinking framework, results of empirical research described above, the following hypotheses can be developed:

H6: Organizational Citizenship Behavior $(O C B)$ weakens the effect of Time Pressure on the performance of auditor KAP in Bali Province.

\section{Materials and Methods}

This research was conducted at the Public Accountant Office (KAP) in Bali Province which was registered in the Directory published by the Indonesian Institute of Certified Public Accountants (IAPI) in 2017. In this study, the population was all auditors in KAP in the Province of Bali. The data collection method used is the survey method with

Adnyana, I. W., \& Mimba, N. P. S. H. (2019). Effect of task complexity and time pressure on auditor performance with compensation and organizational citizenship behavior (OCB) as moderation. International Research Journal of Management, IT and Social Sciences, 6(6), 58-67. https://doi.org/10.21744/irjmis.v6n6.762 
the questionnaire instrument. This research uses Multiple Linear Regression Analysis and Interaction Test or often called Moderated Regression Analysis (MRA).

\section{Results and Discussions}

This study uses multiple linear regression analysis techniques that contain interactions between independent variables or Moderated Regression Analysis (MRA). MRA is a special analysis tool of linear regression in the regression equation containing the element of interaction (multiplying two or more independent variables). This analysis is assisted by using SPSS version 22 and the results can be seen in Table 1 below:

Table 1

MRA Testing Result

\begin{tabular}{|c|c|c|c|c|c|c|}
\hline \multirow{2}{*}{\multicolumn{2}{|c|}{ Model }} & \multicolumn{2}{|c|}{$\begin{array}{l}\text { Unstandardized } \\
\text { Coefficients }\end{array}$} & \multirow{2}{*}{$\begin{array}{l}\text { Standardized } \\
\text { Coefficients } \\
\text { Beta }\end{array}$} & \multirow[t]{2}{*}{ Sig. } & \multirow[t]{2}{*}{ Result } \\
\hline & & $\mathrm{B}$ & Std. Error & & & \\
\hline \multirow[t]{9}{*}{1} & (Constant) & 45,283 & 17,920 & & 0,015 & \\
\hline & $\mathrm{X} 1$ & $-0,638$ & 1,070 & $-0,232$ & 0,553 & \\
\hline & $\mathrm{X} 2$ & 1,452 & 0,741 & 0,624 & 0,055 & \\
\hline & $\mathrm{X} 3$ & 0,183 & 0,192 & 0,233 & 0,345 & \\
\hline & $\mathrm{X} 4$ & $-0,381$ & 0,420 & $-0,271$ & 0,368 & \\
\hline & X1_X3 & 0,008 & 0,011 & 0,169 & 0,479 & H3 Rejected \\
\hline & X2_X3 & $-0,011$ & 0,009 & $-0,219$ & 0,232 & H4 Rejected \\
\hline & X1_X4 & $-0,002$ & 0,024 & $-0,038$ & 0,922 & H5 Rejected \\
\hline & X2_X4 & $-0,041$ & 0,016 & $-0,783$ & 0,016 & H6 Accepted \\
\hline \multicolumn{2}{|c|}{ Adjusted $\mathrm{R}_{\text {square }}$} & 0,776 & & & & \\
\hline \multicolumn{2}{|c|}{ Sig. F } & 0,000 & & & & \\
\hline
\end{tabular}

Primary Data, 2018

Based on Table 1 shows that the results of the study have a compensation regression coefficient (X3) and a moderate coefficient of compensation with task complexity (X1_X3) and time pressure (X2_X3) show a significant level above $\alpha$, so the type of moderation in this study is homologized moderation. The regression coefficient of organizational citizenship behavior (X4) and moderate coefficient of organizational citizenship behavior with task complexity (X1_X4) shows a significant level above $\alpha$, so the type of moderation in this study is homologized moderation. The moderate coefficient of organizational citizenship behavior with time pressure (X2_X4) shows a significant level below $\alpha$, so the type of moderation in this study is the moderation of pure moderator (pure moderation).

F Test

Table 1 shows the Sig. F obtained is 0,000 . This significance is clearly smaller than Alpha $(\alpha=0.05)$, so the regression model has fulfilled the prerequisites for the accuracy of the regression function. This means that this moderation regression model is appropriately used to predict the interaction of compensation variables with task complexity on auditor performance, interaction of compensation variables with time pressure on auditor performance, interaction of variable organizational citizenship behavior with task complexity on auditor performance, interaction of variable organizational citizenship behavior with time pressure on auditor performance.

\section{The Result of Determination Coefficient Analysis (Adjusted R2)}

Table 1 shows that the adjusted R2 is 0.776 . This shows that $77.6 \%$ variation in Auditor Performance can be explained by variables Task Complexity, Time Pressure, Compensation, Organizational Citizenship Behavior (OCB) while the remaining $22.4 \%$ is explained by other variables outside the model. 
Hypothesis Testing Results (t-test)

The interaction variable between task complexity (X1) and compensation (X3) has a moderate coefficient of 0.008 with a significance level of 0.479 . The number sig $\mathrm{t}$ is greater than 0.05 , which means that $\mathrm{H} 0$ is accepted and $\mathrm{H} 1$ is rejected. Then it can be concluded that compensation cannot moderate the relationship between task complexity and auditor performance.

The interaction variable between time pressure (X2) and compensation (X3) has a moderate coefficient of -0.011 with a significance level of 0.232 . The number sig $\mathrm{t}$ is greater than 0.05 , which means that $\mathrm{H} 0$ is accepted and $\mathrm{H} 1$ is rejected. Then it can be concluded that compensation cannot moderate the negative relationship between time pressure and auditor performance.

The interaction variable between task complexity (X1) and organizational citizenship behavior (X4) has a moderate coefficient of -0.002 with a significance level of 0.922 . The number sig $\mathrm{t}$ is greater than 0.05 , which means that $\mathrm{H} 0$ is accepted and $\mathrm{H} 1$ is rejected. Then it can be concluded that organizational citizenship behavior cannot moderate the negative relationship between task complexity and auditor performance.

The interaction variable between time pressure (X2) and organizational citizenship behavior (X4) has a moderate coefficient of -0.041 with a significance level of 0.016 . The number sig $\mathrm{t}$ is smaller than 0.05 , which means that $\mathrm{H} 0$ is rejected and $\mathrm{H} 1$ is accepted. It can be concluded that the existence of organizational citizenship behavior will weaken the negative influence of time pressure on auditor performance.

\section{The Effect of Time Pressure on Auditor Performance}

Based on the results of these studies it can be seen that the time pressure regression coefficient has a negative sign and the significant value of $t$ is smaller than the value of $\alpha$. This means that the second hypothesis which states the time pressure has a negative effect on auditor performance is acceptable. This shows that the less or the tighter the time an auditor has, the auditor's performance will tend to decrease.

This research is in line with research conducted by Lautania (2011), which states that time pressure has a negative effect on auditor performance. This indicates that the auditor feels pressured by the time pressure, which can lead to stress on the auditor and will eventually encourage the auditor to violate audit standards or dysfunctional audits that will result in poor auditor performance.

These results indicate the importance of placing appropriate values on the audit function to ensure adequate time budgets. Because the more auditors are limited or experiencing pressure in finding audit findings, the audit quality produced indirectly affects the performance of auditors who tend to be lower.

The descriptive statistics table also explains that the Public Accountant Office needs to pay attention to several factors, such as the auditor's ability to share audit time and auditor effectiveness in using the audit time. It could also be because the auditor is still forcing himself to take client requests.

\section{Compensation Moderates the Effects of Task Complexity on Auditor Performance}

Based on the results of calculations using the Moderated Regression Analysis (MRA) test. The moderate coefficient of interaction between the complexity of the task and compensation has a positive sign and the significant value of $t$ is greater than the value of $\alpha$. This means that the third hypothesis that states compensation weakens the negative influence of task complexity on auditor performance is unacceptable.

In the results of research conducted by Sanusi et al., (2007), which shows that when auditors have complex or unstructured tasks, no matter how high the auditor's efforts will be difficult to complete the work properly so that it decreases the auditor's performance. In his research also explained that simply increasing compensation would not improve the performance of an auditor whose abilities were lacking. It is not a motivation for auditors but instead becomes a burden on the auditor because with large compensation but insufficient knowledge, the auditor will actually feel a greater responsibility. It can be likened that auditors who have the low ability have the ability far from enough to solve the problems faced so that it does not improve performance but on the contrary is decreasing its performance.

These results can also be justified from the characteristics of the respondents, namely that most respondents who filled out the questionnaire were junior auditors and whose work period ranged from 1-3 years and received less training so that it could be concluded that if the ability is not sufficient to solve the problem the amount of compensation to be given the auditor will not assist the auditor in completing his work. Not only compensation needed by the auditor

Adnyana, I. W., \& Mimba, N. P. S. H. (2019). Effect of task complexity and time pressure on auditor performance with compensation and organizational citizenship behavior (OCB) as moderation. International Research Journal of Management, IT and Social Sciences, 6(6), 58-67. https://doi.org/10.21744/irjmis.v6n6.762 
in helping to overcome or deal with the complexity of a task, but must be balanced by adequate knowledge and experience.

\section{Compensation Moderates the Effects of Time Pressure on Auditor Performance}

Based on the results of calculations using the Moderated Regression Analysis (MRA) test. The moderate coefficient of interaction between time pressure and compensation has a negative sign and significant $t$ value is greater than the value of $\alpha$. This means that the fourth hypothesis that states compensation weakens the negative influence of time pressure on auditor performance is not acceptable.

Compensation is all income received by employees in the form of money, goods directly or indirectly which is a form of costs that must be incurred by the company in the hope of obtaining benefits in the form of work performance from employees (Hasibuan, 2014; Sofyandi, 2008). Compensation that is in accordance with the work that has been done will give encouragement to the auditors to keep trying to complete the work. But even with high compensation, it is still only able to motivate an auditor but does not increase the time budget. Then it can be interpreted not just a large amount of compensation that the auditor needs to have but something that helps the auditor to reduce time in completing work such as time management.

The results of the questionnaire obtained in the time pressure questionnaire, the point which states that "I often have difficulty implementing or completing certain audit procedures because of limited audit time" and "I face difficulties because of insufficient time to complete each audit procedure" has pointed the lowest. This clearly shows that what the auditors might need to have is how to overcome the time to complete audit procedures.

\section{Organizational Citizenship Behavior Moderates the Effect of Task Complexity on Auditor Performance}

Based on the results of calculations using the Moderated Regression Analysis (MRA) test. The moderate coefficient of interaction between the complexity of the task and organizational citizenship behavior (OCB) has a negative sign and the significant value of $t$ is greater than the value of $\alpha$. This means that the fifth hypothesis that states organizational citizenship behavior (OCB) weakens the negative influence of task complexity on auditor performance is unacceptable. OCB is employee behavior that exceeds the required role. The contribution shown by the worker is not only from his job but also in the form of work outside of the work that he must do, the worker shows helping behavior to others in a company so that the action might improve the performance of the organization or company (Robbins \& Judge, 2008). But if it is associated with the complexity of the task it will still relate to how the auditor completes his work, and how the auditor's ability to solve the problem at the job. When someone has OCB behavior, it might be useful if the situation at hand can be overcome with their abilities, but if their ability is lacking in completing a job, it will be the same that the complex task will be difficult to deal with or resolve.

The auditor must know how to do each type of task. The auditor must also know clearly the tasks he is doing. But in the questionnaire data that has been obtained get the results that at that point have the lowest value. These results indicate that the problem is the lack of auditor knowledge and experience in completing existing tasks. So even though in a Public Accountant Office each auditor has a high OCB behavior but is not balanced with a good task in overcoming a case, then it only has a slight impact in reducing the complexity of the task on the auditor's performance.

\section{Organizational Citizenship Behavior Moderates the Effects of Time Pressure on Auditor Performance}

Based on the results of calculations using the Moderated Regression Analysis (MRA) test. The moderate coefficient of interaction between time pressure and organizational citizenship behavior (OCB) has a negative sign and the significant value of $t$ is smaller than the value of $\alpha$. This means that the sixth hypothesis that states organizational citizenship behavior (OCB) weakens the negative influence of time pressure on auditor performance is acceptable. This shows that the higher the organizational citizenship behavior (OCB) behavior owned by the auditor, the weaker the negative influence of time pressure on auditor performance.

By having this OCB behavior, the auditor can play an extra role beyond the demands of formal work, and not be egocentric. All organizations need potential and productive employees to function (Cascio in Teresia and Suyasa, 2008). If you want to function effectively, you need a workforce that does not only work in accordance with its main tasks to complete the task, but also does things outside the job description, for example by helping coworkers to complete tasks when work colleagues face many tasks, although not their duties and responsibilities. 
Fitriastuti (2013), study also support the results of this study, namely organizational citizenship behavior (OCB), which has a significant positive effect on employee performance. By having this OCB behavior, the employee will not question the time pressure given by the company or the client.

So by having an Organizational Citizenship Behavior (OCB) behavior, the auditor will carry out all his work happily, which later will not question the time that the auditor will use in completing his tasks. Auditors will also always do overtime or use holidays to complete their work. In addition to improving the performance of the auditor itself, having an $\mathrm{OC}$ will also improve the performance of his teammates or office colleagues, because someone who has OCB will always help the work of his colleague, where previously the work will be done to the fullest.

\section{Conclusion}

KAP in Bali Province needs to foster organizational citizenship behavior (OCB) in their respective auditors. With the behavior of organizational citizenship behavior, the work done will be more easily and quickly resolved. This is very helpful for the psychology of auditors because it will reduce the stress levels of the auditors.

In addition, the auditors should also be given special training in each audit procedure so that the auditor will be better able to manage their work so that the auditor can shorten the time the work is carried out and also with the training that the auditor is expected to reduce the complexity of the task. In accordance with the results of the questionnaire, it was found that there were still many auditors who did not understand in carrying out their audit procedures and the auditors also still lacked understanding in overcoming their duties.

\section{Research Limitations}

The limitations of this study are that the auditor's performance variable does not refer to article 4 of 2018 regarding audit quality indicators. Because of the same time when the researcher determines the auditor's performance indicators, so the researcher does not fully refer to the article.

For further research, use article 4 of 2018 concerning audit quality indicators as a basis for determining research indicators. Based on the results of the questionnaire in this study, the next researcher can do research again on the variable audit supervision and audit structure because in this study found that there were problems regarding these variables to the auditor at the Bali Provincial Public Accountant Office.

\section{Conflict of interest statement}

The authors declared that they have no competing interests.

Statement of authorship

The authors have a responsibility for the conception and design of the study. The authors have approved the final article.

\section{Acknowledgments}

We thank the editor of IRJMIS for their valuable time, support and advice.

Adnyana, I. W., \& Mimba, N. P. S. H. (2019). Effect of task complexity and time pressure on auditor performance with compensation and organizational citizenship behavior (OCB) as moderation. International Research Journal of Management, IT and Social Sciences, 6(6), 58-67. https://doi.org/10.21744/irjmis.v6n6.762 


\section{References}

Aditya, A. G. D., \& Kusuma, M. G. W. (2019). The effect of tri hita karana culture in relationship between work stress and internal auditor performance. International Research Journal of Management, IT and Social Sciences, 6(2), 72-78. https://doi.org/10.21744/irjmis.v6n2.610

Ahituv, N., Igbaria, M., \& Sella, A. V. (1998). The effects of time pressure and completeness of information on decision making. Journal of management information systems, 15(2), 153-172.

Basuki, B., \& Mahardani, K. Y. (2006). Pengaruh tekanan anggaran waktu terhadap perilaku disfungsional auditor dan kualitas audit pada kantor akuntan publik di Surabaya. Jurnal Manajemen, Akuntansi \& Sistem Informasi, 6(2), 203-223.

D’yan, M. V. J. P., \& Yaniartha, S. (2013). Pengaruh tekanan anggaran waktu, kompleksitas tugas dan reputasi auditor terhadap fee audit pada kantor akuntan publik (KAP) di bali. E-Jurnal Akuntansi, 132-146.

Dhermawan, A. A. N. B., Sudibya, I. G. A., \& Utama, I. W. M. (2012). Pengaruh motivasi, lingkungan kerja, kompetensi, dan kompensasi terhadap kepuasan kerja dan kinerja pegawai di lingkungan kantor Dinas Pekerjaan Umum Provinsi Bali. Matrik: Jurnal Manajemen, Strategi Bisnis dan Kewirausahaan.

Fitrianasari, D., Nimran, U., \& Utami, H. N. (2013). Pengaruh Kompensasi dan Kepuasan Kerja terhadap Organizational Citizenship Behavior (OCB) dan Kinerja Karyawan (Studi pada Perawat Rumah Sakit Umum "Darmayu" di Kabupaten Ponorogo). Profit (Jurnal Administrasi Bisnis), 7(1).

Fitriastuti, T. (2013). Pengaruh Kecerdasan Emosional, Komitmen Organisasional dan Organizational Citizenship Behavior terhadap Kinerja Karyawan. Jurnal Dinamika Manajemen, 4(2).

Gayatri, K. D. P., \& Suputra, I. D. G. D. (2016). Pengaruh Struktur Audit, Tekanan Waktu, Disiplin Kerja dan Komitmen Organisasi pada Kinerja Auditor. E-Jurnal Akuntansi, 1366-1391.

Govindarajan, V. (1986). Decentralization, strategy, and effectiveness of strategic business units in multibusiness organizations. Academy of Management Review, 11(4), 844-856. https://doi.org/10.5465/amr.1986.4284099

Hasibuan, M. S. (2014). Manajemen sumber daya manusia (revisi). Jakarta: Bumi Aksara.

Jamilah, S., Fanani, Z., \& Chandrarin, G. (2007). Pengaruh gender, tekanan ketaatan, dan kompleksitas tugas terhadap audit judgment. Simposium Nasional Akuntansi X, 26-28.

Juliantini, N. K. D., Sudana, I. P., Suprasto, H. B., \& Putri, I. G. A. M. A. D. (2019). Gender and work-life balance: A phenomenological study on Balinese female auditor. International Journal of Social Sciences and Humanities, 3(2), 224-237. https://doi.org/10.29332/ijssh.v3n2.318

Lautania, M. F. (2011). Pengaruh Time Budget Pressure, Locus Of Control dan Perilaku Disfungsional Audit Terhadap Kinerja Auditor (Studi Pada Kantor Akuntan Publik Indonesia). Jurnal Telaah dan Riset Akuntansi, 4(1), 92-113.

Libby, R., \& Lipe, M. G. (1992). Incentives, effort, and the cognitive processes involved in accounting-related judgments. Journal of Accounting Research, 30(2), 249-273. https://doi.org/10.2307/2491126

Liyanarachchi, G. A., \& McNamara, S. M. (2007). Time budget pressure in New Zealand audits. University of Auckland Business Review, 9(2), 60.

Murray, Keith B., and John L. Schlacter. "The impact of services versus goods on consumers' assessment of perceived risk and variability." Journal of the Academy of Marketing science 18, no. 1 (1990): 51-65. https://doi.org/10.1007/BF02729762

Podsakoff, P. M., MacKenzie, S. B., Paine, J. B., \& Bachrach, D. G. (2000). Organizational citizenship behaviors: A critical review of the theoretical and empirical literature and suggestions for future research. Journal of management, 26(3), 513-563. https://doi.org/10.1016/S0149-2063(00)00047-7

Putra, I. G. B. W., \& Sudana, I. P. (2019). Effect of auditor's role conflict on auditor's stress with core self-evaluations as moderators. International Research Journal of Management, IT and Social Sciences, 6(4), 147-155. https://doi.org/10.21744/irjmis.v6n4.669

Restuningdiah, J. Nurika dan Nur Indriantoro. 2000.”. Pengaruh Partisipasi terhadap Kepuasan Pemakai dalam Pengembangan System Informasi dengan Kompleksitas.

Robbins, S. P., \& Judge, T. A. (2008). Perilaku organisasi (Organizational behavior). Jakarta: Salemba Empat.

Sanusi, Z. M., Iskandar, T. M., \& Poon, J. M. (2007). Effects of goal orientation and task complexity on audit judgment performance. Malaysian Accounting Review, 6(2).

Septian, I., \& Astika, I. B. P. (2019). Halo effect moderating: impact of professional skepticism on auditor performance. International Research Journal of Management, IT and Social Sciences, 6(4), 189-196. https://doi.org/10.21744/irjmis.v6n4.680

Sofyandi, H. (2008). Manajemen Sumber Daya Manusia, Graha Ilmu. 
Sososutiksno, C. (2003). Hubungan tekanan anggaran waktu dengan perilaku disfungsional serta pengaruhnya terhadap kualitas audit (Doctoral dissertation, Universitas Gadjah Mada).

Supatmi, M. E., Nimran, U., \& Utami, H. N. (2013). Pengaruh pelatihan, kompensasi terhadap kepuasan kerja karyawan dan kinerja karyawan. Profit (Jurnal Administrasi Bisnis), 7(1).

Teresia, N., \& Suyasa, P. T. Y. S. (2008). Komitmen Organisasi dan Organizational Citizenship Behavior pada Karyawan Call Centre di PT. X. Phronesis Jurnal Ilmiah Psikologi Industri dan Organisasi, 10(2), $154-169$.

Winardi, J. J., \& Ma'aruf, S. M. (2012). Pengaruh Budaya Organisasi dan Motivasi Terhadap Kinerja Karyawan dengan Komitmen Organisasional Sebagai Variabel Intervening. Provinsi Aceh.

Adnyana, I. W., \& Mimba, N. P. S. H. (2019). Effect of task complexity and time pressure on auditor performance with compensation and organizational citizenship behavior (OCB) as moderation. International Research Journal of Management, IT and Social Sciences, 6(6), 58-67. https://doi.org/10.21744/irjmis.v6n6.762 